\title{
On the construction of business ethics in the horizon of system ethics
}

\author{
Mu Huaiqin
}

\author{
Xijing University, No.1, Xijing Road, Shaan Xi, 710123, China
}

Keywords: system, ethics, enterprise moral

\begin{abstract}
Enterprise management moral is the behavior standard to managerial behavior, and the "moral landslide" is refers to backward moral disdained by people with money worship, hedonism, selfish. The main outstanding behavior of enterprise "moral landslide" refers to falsification, unfair competition, pollution of the environment, violations of the rights of employees and stakeholders, etc. This paper analyzes the reason of moral landslide, and the resulting negative impact. Pointed out that to solve the "moral landslide" of the enterprise, must strengthen the enterprise ethics management, only understand the importance of moral can enterprise gain better development, to establish perfect moral management system, to perform the social responsibility as a social organization, secure their place in society. Attention in the development of enterprises should not only be put on the profit, but put the development of the enterprise into the society at the same time, under the era of big background. Focus on the development of the enterprise internal, at the same time, must also pay attention to the social dynamic, carry out the duties as a social organization members, this can be more conducive to enterprise in existing sustainable.
\end{abstract}

\section{Introduction}

Nowadays, most enterprises only care about benefit in order to exist. What they believe is as Churchill said: "no permanent friends, nor permanent enemies, only permanent benefits." Perhaps this is the survival principle what the enterprises paid great attention to in the process of the development. Perhaps in their eyes, the wisdom between the great powers is same, and we're just a social organization. In my opinion this is wrong, "The book of rites. Great learnin" is put forward that only the leader of a country is moral will he supported by people, only supported by people will have land, having the land is having the wealth, then they can use the wealth. Morality is the most fundamental and the wealth is the least important. A gentleman should first pay attention to their own moral accomplishment. If they ignore the fundamental thing to value what is not important, they will fight with people the benefits. We believe that if a person is very talented, but has no certain moral accomplishment time of meeting people, he will not be able to realize the value of the self, in other words, if a person just keep the wealth and power, may fall in end, such as enterprise. The enterprise ethics gradually formed in the long-term production and operation practice, according to the rights and obligations borne by an enterprise, relying on public opinion, traditions and inner conviction to maintain, in a certain society consciously follow the sum total of all kinds of ethical principles and norms. Enterprise management ethics is behavior standards to the guider of management work, is an enterprise standards and guidelines in dealing with internal and external environment related problem.

And the "moral landslide" is refers to backward moral disdained by people with money worship, 
hedonism, selfish. It started to develop, and began to affect young people, we call this performance in the field of ideology, and affecting people's behavior moral degeneration phenomenon as "moral landslide". "Moral landslide" refers to the enterprises engaged in misconduct behavior over and over again as a result of the phenomenon of sharp decline in moral standards.

\section{The analysis on present situation of the enterprise ethics construction.}

\subsection{The performance of enterprises "moral landslide"}

Market in our country's economy, when an enterprise begins to think that immoral behavior can bring more generous benefits for the enterprise, then in the next time, the company will "hold" towards in a queue of the moral landslide.

Enterprise "moral landslide" main outstanding behavior is for falsification, unfair competition, environmental pollution and invasion on the rights of employees and stakeholders, etc. Specific embodied in the following aspects:

First of all is the "moral landslide" on the relationship between enterprise and customer. In order to promote sale, enterprise exaggerated, fraud, use fake and shoddy goods, deceive the legitimate rights and interests of consumers.

The second one is the "moral landslide" of the relation between the enterprise and competitors. Enterprises compete by undermining the rival business reputation, treating competitors without credit, defaulting to each other, ignoring the market rules of the game. Therefore bring serious consequences of market transaction order and credit crisis frequent.

Next is the "moral landslide" performance of the relation between employees. Some enterprises blindly pursuing profits, regardless of employees' living and working environment, even squeezing the employee's salary, don't respect the legitimate interests of the employees. Their opinions carry doctrine.

Finally is the "moral landslide" performance to the relation between enterprise and environment. In the pursuit of high profits, low cost, Enterprises do not actively control the pollution caused by the discharge of waste gas, waste water, waste residue, etc.. The social environment has caused serious pollution.

Enterprise moral landslide is becoming worse and worse, causing the whole society is in a state of disharmony, between people and enterprises and enterprises is gradually lacking of credit, if we don't hurry up to treatment the situation, more cannot imagine consequences will appear.

\subsection{The analysis of the causes of enterprise "moral landslide"}

In this era of economic improvement, why the moral level of society as a whole is increasingly low? Investigate its reason, the author sums up the following points:

Influenced by social bad cultural of "caring about profit, despising morality" under the condition of market economy.

It is well known that the enterprise is social organizations purposing on profit, the fundamental goal is to realize the maximization of the profit of enterprise. But in the level of interest, there is no right or wrong, it doesn't matter if it is immoral. For enterprises, in the social market environment, there is only the interests and survival, and its survival is dependent on the continuous profit. Therefore, when the enterprise is facing with the benefit and the survival, all ethics and morals are meaningless. In today's society, on the one hand, enterprises are facing a changing competitive environment, on the other hand, the enterprise is always dealing with all the changes by no change. Therefore, under such a choice, in order to allow enterprises to continue to survive in this social environment, many enterprises in our country gradually joined the ranks of moral decline and stride forward. 


\section{The negative influence of enterprise "moral landslide".}

Enterprise moral landslide is spreading in the socialist market economy, gradually polluted the economic market soil in China by different degrees. With the more and more fiercely trend of the landslide, The phenomenon of "attaching importance to interests and despising morality" is becoming more and more serious.

\subsection{Enterprise "moral landslide" seriously endanger the social moral level, is not conducive to the construction of a harmonious society.}

Enterprise "moral landslide" is not only conducive to the healthy development of society, but also corrupt society at the same time, affect social harmony. As the cells of market, healthy development of enterprise is conducive to social progress. A person suffering from cancer, if not timely to treatment, the tumor will spread throughout the body, eventually leading to paralysis of the entire body function. This is like the relationship between the enterprise and the whole social system, when a particular cell appear abnormalities in the social organization, the first thing to do is to remove the disease, the only way to keep the fundamental.

\subsection{Enterprise "moral landslide" reduce the overall level of the enterprise and hinder the long-term development of enterprise.}

The sharp decline in the level of corporate ethics leads to a credit crisis in the whole society, and enterprises begin to lose their customers. "Analects of Confucius" mentioned: if a person does not keep good faith, he will can not live in society. For enterprises, the sincerity is important in today's market. However, those of enterprise who lose the professional ethics, regardless of ethics, blind pursuit of profit, has become a social responsibility moral dwarf, which led to the closure of enterprises, no doubt this is a short-sighted behavior.

4. In order to solve the problem of "moral decline", it is necessary to strengthen the management of enterprise morality.

Since the birth of enterprise, ethics and responsibility that enterprise as a social organization should bear has became its inherent elements, we can understand that, ethics in market economy is the core value of the enterprise and social responsibility is the embodiment of the enterprise's core values. Enterprises want to survive in the society for a long time, it must also keep the moral and responsibility.

In the highly competitive and changeable market economy society, profit decides the fate of every enterprise. Therefore, some operators pursuit for profits, using of a variety of illegal methods. Ethical competition can exist in a short time, but it can't exist forever. Illegal competition may win a short-term victory in business competition, but it is difficult to exist in the market forever. This paper points out the influence of moral management on the survival of enterprises.

4.1 Improve the social atmosphere and create an atmosphere of moral and interest at the same time.

Social atmosphere is the comprehensive expression of social economy, politics, ideology, culture, morality and legal system. Good social atmosphere needs to rely on good moral order to maintain. But if society pursues utilitarianism, morality loses its meaning of existence. "Sanlu incident" and "Shuanghui lean meat" and other food safety incidents are not accident, it is because of the deterioration of the social atmosphere in the environment, caused by the weak of the enterprise moral management. Therefore, to create a good social atmosphere, the construction of enterprise moral management has a very important guiding role. 


\subsection{Make rational use of the traditional scientific management concept and attach importance to the combination of system and humanity.}

For a long time, the traditional culture of our country has emphasized the moral cultivation of human being, but with the development of economy, the western culture has gradually come into. However, due to the conflict between the traditional the original idea of our country and western scientific management idea, there is a great deal of problems in the system of management idea. The traditional concept of scientific management of Western emphasis focus on material products, capital and profit management, rigid machinery management, such management concept of one-sided emphasis on scientific management, imperceptibly ignores the moral and humanistic management.

For the western traditional scientific management concept, we should learn from it dialectically. It's like that not all plants are suitable for living in a greenhouse. Therefore, not all management ideas are suitable for enterprises in china. In the countries that pay attention to the development of ethics and morality, it can not be managed by a single scientific system, nor can it be maintained on the basis of ethics. If the enterprise wants to be based on the society for a long time, it is necessary to integrate the system management and human management.

\subsection{Strengthen the moral cultivation of enterprise managers, establish a good image of the enterprise.}

The of the enterprise undertakes the responsibility of the enterprise, and also undertakes the moral responsibility and social responsibility of the enterprise. Managers in addition to charge of the enterprise, be responsible for the society and for individual development of employees, therefore, entrepreneurs must do reflect on their behavior every day, and constantly improve the individual moral cultivation. To establish a good image In front of the staff, to guide the staff in the right direction, to lay a good foundation for the future development of enterprises.

The ancients said that a person needs to establish a correct idea, and then improve their self-cultivation, manage family, so that get the country's stability, can achieve the aspirations of world peace. It is of the same importance for an enterprise to develop in the long term in the social trend. In the enterprise, the manager is the leader, only the managers to improve their moral cultivation, can they manage the enterprise, at the same time, cultivate more talent with conservation, attracting more talents.

\subsection{Improve the moral quality of enterprise employees.}

Paying attention to the moral education of the staff is the foundation of enterprise development and survival. The moral education of the staff makes the enterprise win the appreciation of the customers and the public, accumulate the social credit, so as to obtain a good corporate image and improve the reputation of the enterprise in the public mind. This is undoubtedly a valuable intangible assets for enterprises. With the deepening of reform and opening up, China's socialist market economy has made long-term development, and the construction of material civilization has also risen to a new stage. However, as a result of a period of time, that the enterprise lacks the moral education to the staff, causes that the staff in the enterprise management cannot carry on the enterprise production and management activity from the moral angle of view.

\section{Conclusion}

With the deepening of reform and opening up, China's socialist market economy has made great progress. In accordance with the principle, after being able to eat and wear warm, people will begin to understand the etiquette, know the honor. But the fact is not the case, the enterprise in the pursuit 
of interests, in order to obtain higher profits, abandon the moral and integrity. The main reason is that people are indifferent to moral consciousness. To sum up, only to construct the enterprise moral system compatible with the socialist market economy, only to purify the existing moral environment in our country, Chinese enterprises can get out of the moral predicament existing, undertake corporate social responsibility as a social organization should do.

\section{References}

[1] Song Yifeng. Enterprise managers' moral dilemma and countermeasures [J]. Journal of handan teachers college, 2000, 2000:172-173.

[2] Li Yuan. Enterprise culture is the first impetus of leadership [J]. Chinese and foreign management, 2006, cutflower production potentials: 35.

[3] Wang Zhijie. University education management discipline and moral construction [J]. China's adult education, 2003, 10:57.

[4] Zhao Li. Analyses the importance of enterprise staff should have good professional ethics [J]. Modern business, the preceding 2011.

[5] Wang Chunlan. Gold jewelry corporate image shaping [J]. Heilongjiang province's foreign economic and trade, 2011, 10, 77-78.

[6] Qian Gaoyuan. Enterprise ethics [M]. Beijing: China textile press, 2000.

[7] Wang Dingding. The market economy and moral foundation [M]. Shanghai: Shanghai people's publishing house, 2007-01. 